\title{
FAKTOR YANG MEMPENGARUHI KINERJA KEUANGAN PERUSAHAAN PADA PERUSAHAAN PROPERTY DAN REAL ESTATE
}

\author{
Vidyarto Nugroho \\ Universitas Tarumanagara Jakarta \\ vidyartonugroho@yahoo.co.id \\ Nicholas \\ Universitas Tarumanagara Jakarta \\ nico_owning@yahoo.com
}

\begin{abstract}
:
The purpose of this research is to analyze the effect of leverage, liquidity, firm size, and firm age oncompanies financial performance in property and real estate companies listed on Indonesia Stock Exchange in 2015 - 2017. The sampling method used purposive sampling with total sample 105 data which was financial statement from www.idx.co.id. The collected data were analyzed by using Eviews 10. The research result that independent variables describe the dependent variable up to $72.54 \%$, while $27.46 \%$ is described by other factors. Independent variable leverage, firm size, and firm age do not have a significant effect on firm value, while the liquidity have a significant effect on companies financial performance.
\end{abstract}

Keywords:leverage, liquidity, firm size, firm age, financial performance

\section{PENDAHULUAN}

Sektor properti dan real estate merupakan salah satu dari sekian banyak instrumen jenis industri yang banyak dijadikan pilihan dalam berinvestasi oleh para investor. Saat ini, banyak investor memilih alternatif untuk berinvestasi di sektor properti dan real estate yang merupakan investasi jangka panjang dan memiliki aktiva multiguna yang dapat digunakan oleh perusahaan sebagai jaminan. Oleh karena itu, perusahaan di bidang properti dan real estate memberikan return yang cukup besar apabila dijadikan pilihan untuk berinvestasi dalam jangka waktu yang panjang. Di Indonesia, sektor properti dan real estate telah mengalami pertumbuhan yang tampaknya tak terhentikan selama beberapa dekade terakhir. Suatu keberhasilan pada sektor properti dan real estate tentunya tidak lepas dari kebijakan-kebijakan yang diambil oleh manajer pada suatu perusahaan. Dalam dunia persaingan, perusahaan diharapkan dapat mempertahankan dan meningkatkan kinerjanya agar dapat unggul dalam bersaing dengan 
perusahaan lain. Kinerja adalah hasil dari suatu pemenuhan tugas yang diberikan. Kinerja keuangan memainkan peran penting dalam menentukan keberhasilan kinerja perusahaan yang dinyatakan dalam istilah moneter. Kinerja keuangan menekankan kepada variabel-variabel yang terkait secara langsung dengan laporan keuangan. Sebelum menginvestasikan dana, investor terlebih dahulu harus mengetahui tentang kinerja perusahaan tempat mereka menginvestasikan dana mereka. Cara paling sederhana bagi investor untuk menentukan keberhasilan kinerja suatu perusahaan adalah dengan melihat laporan keuangan yang dihasilkan oleh perusahaan tersebut.

\section{TELAAH LITERATUR}

Teori keagenan merupakan teori yang menjelaskan hubungan antara pemilik perusahaan (pemegang saham) sebagai prinsipal dan manajemen sebagai agen. Jensen dan Meckling menyatakan hubungan keagenan adalah suatu kontrak dimana satu orang atau lebih (principal) memerintah orang lain (agent) untuk melakukan suatu jasa atas nama pincipal dan memberikan wewenang kepada agent untuk
Kinerja keuangan perusahaan merupakan salah satu tolak ukur yang dipakai oleh para investor maupun para kreditur untuk menanamkan serta meminjamkan dana mereka kepada suatu perusahaan. Kinerja keuangan perusahaan dapat dinilai dari beberapa aspek-aspek di dalam suatu perusahaan, seperti leverage, likuiditas, ukuran perusahaan, dan umur perusahaan. Ada banyak faktor yang dapat mempengaruhi kinerja keuangan perusahaan, namun dalam penelitian ini hanya digunakan empat faktor yang dapat mempengaruhi kinerja keuangan perusahaan, antara lain leverage, likuiditas, ukuran perusahaan, dan umur perusahaan.

membuat suatu keputusan yang terbaik bagi principal. Pada teori keagenan, baik agen maupun prinsipal diasumsikan selalu bertindak untuk kepentingannya sendiri. Manajemen dalam teori ini sering dianggap menggunakan wewenang yang dimiliki untuk kepentingan dirinya sendiri, sehingga kepentingan prinsipal diabaikan. Hal tersebut dilakukan manajemen karena adanya perbedaan tujuan, latar belakang, dan keinginan 
dengan prinsipal. Akibat dari perbedaan tersebut, dapat memunculkan konflik kepentingan diantara keduanya. Manajemen dapat merugikan prinsipal atas apa yang dilakukannya. Dalam teori agensi, perbedaan tujuan dan kepentingan tidak hanya melibatkan manajemen dan pemegang saham, namun banyak juga pihak - pihak lain. Terdapat ada tiga macam konflik kepentingan yang bisa terjadi pada perusahaan, yaitu pemegang saham dengan manajemen, pemegang saham dengan kreditur, dan manajemen dan bawahan. Dengan adanya konflik konflik tersebut, maka dapat timbul masalah yang disebut masalah keagenan (agency problem). Teori sinyal mengasumsikan bahwa informasi yang diterima oleh pihak yang ada di dalam perusahaan maupun diluar perusahaan tidak sama. Oleh karena itu, teori sinyal sangat berkaitan dengan asimetri informasi. Teori sinyal menjelaskan bahwa terdapat asimetri informasi antara manajemen perusahaan dengan pihak - pihak yang berkepentingan dengan informasi. Untuk mengatasi hal tersebut, manajemen perusahaan perlu memberikan informasi - informasi kepada pihak yang berkepentingan dengan cara menerbitkan laporan keuangan. Menurut Brigham dan Houston (2006) pengertian dari isyarat atau signal adalah suatu tindakan yang diambil oleh manajemen perusahaan yang memberikan petunjuk bagi para investor tentang bagaimana pandangan manajemen terhadap prospek suatu perusahaan. Informasi yang ada di dalam laporan keuangan berguna untuk para investor dan pelaku bisnis karena informasi yang ada di dalam laporan keuangan menyajikan keterangan, catatan, dan gambaran tentang keadaan perusahaan pada masa lalu, saat ini maupun masa yang akan datang bagi kelangsungan hidup suatu perusahaan. Kerangka pemikiran dalam penelitian ini digambarkan seperti dibawah ini 
Gambar 1 Kerangka Pemikiran

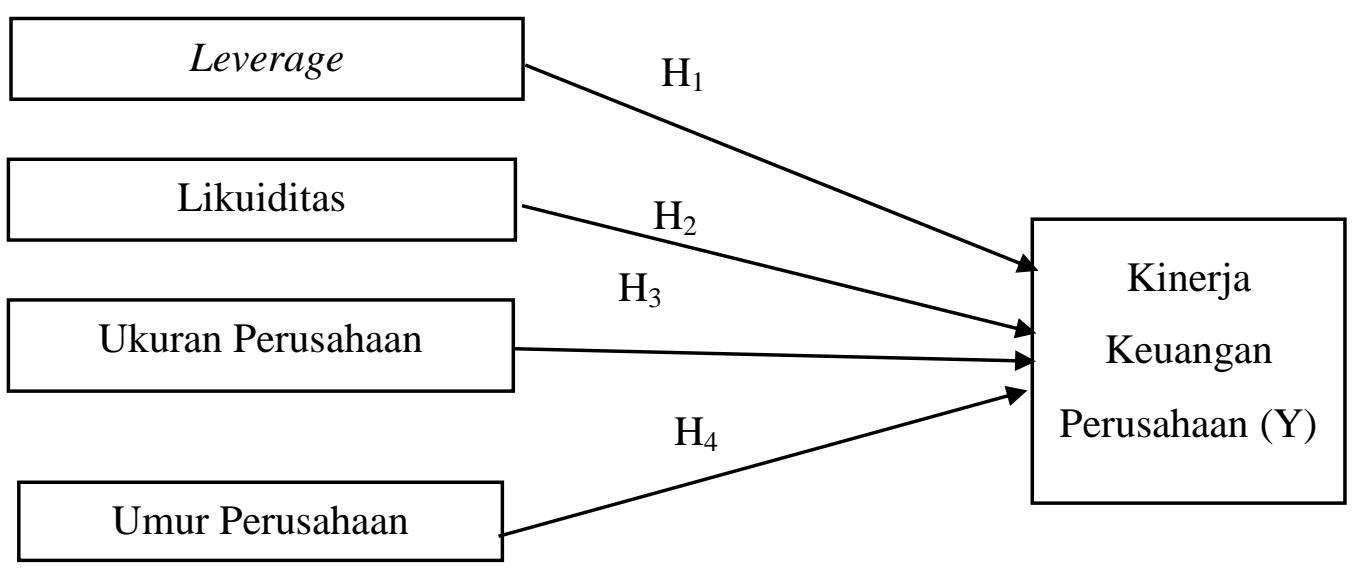

Ha1: Leverage memiliki pengaruh positif dan signifikan terhadap kinerja keuangan perusahaan.

Ha2: Likuiditas memiliki pengaruh negatif dan signifikan terhadap kinerja keuangan perusahaan.

\section{METODOLOGI}

Penelitian ini dilakukan dengan menggunakan metode kuantitatif dan dengan desain penelitian kausalitas. Kausalitas merupakan desain penelitian yang digunakan untuk menggambarkan variabel dependen yang dipengaruhi oleh variabel independen yang berbeda. Variabel independen yang digunakan adalah leverage, likuiditas, ukuran perusahaan, dan umur perusahaan. Sedangkan, variabel dependen yang
Ha3: Ukuran Perusahaan memiliki pengaruh positif dan signifikan terhadap kinerja keuangan perusahaan.

Ha4: Umur Perusahaan memiliki pengaruh positif dan signifikan terhadap kinerja keuangan perusahaan.

digunakan dalam penelitian ini adalah kinerja keuangan perusahaan. Menurut Sugiyono (2007:116) dalam R. Pantow, Murni, Trang (2015) sampel adalah karakteristik serta bagian dari jumlah yang dimiliki oleh populasi tersebut.Dalam penelitian ini, teknik pemilihan sampling yang digunakan adalah purposive sampling. Oleh karena itu, perusahaan yang menjadi subjek penelitian ini ditentukan berdasarkan kriteria tertentu : (a) Perusahaan 
property dan real estate yang terdaftar di Bursa Efek Indonesia selama periode 2015 - 2017, (b) Perusahaan yang laporan keuangannya telah diaudit yang berakhir pada 31 Desember, (c) Perusahaan yang tidak mengalami delisting, relisting, dan IPO pada tahun 2015 - 2017, (d) Laporan keuangan yang dinyatakan dalam Rupiah, (e) Perusahaan manufaktur yang melaporkan laba bersih selama tiga tahun yaitu periode 2015 - 2017 .
Populasi yang digunakan untuk pemilihan sampel adalah sebanyak 144 perusahaan dan jumlah sampel yang memenuhi kriteria adalah 35 perusahaan dengan total sampel selama empat tahun penelitian adalah 105 sampel. Dalam penelitian ini, variabel dependen yang digunakan adalah nilai perusahaan yang di proksikan oleh Return on Assets dengan formula:

$$
\text { Return on Assets }(R O A)=\frac{\text { Net Income }}{\text { Total Assets }}
$$

Sedangkan penulis dalam melakukan ini diukur dengan rumus sebagai perumusan Leverage dalam penelitian berikut:

$$
\text { Debt-to-Equity Ratio }(D E R)=\frac{\text { Total Debt }}{\text { Total Equity }}
$$

Untuk likuiditas dalam penelitian ini dengan rumus sebagai berikut antara penulis menggunakan alat pengukuran lain dapat dilihat dibawah ini:

$$
\text { Current Ratio }=\frac{\text { Current Asset }}{\text { Current Liabilities }}
$$

Sedangkan untuk ukuran perusahaan menggunakan pengukuran dengan dalam penelitian ini penulis rumus sebagai berikut:

$$
\text { Firm Size }=\text { Logarithm Natural (Ln) of Total Asset }
$$


Umur perusahaan dalam penelitian ini diukur dengan menggunakan proksi
Debt to Equity Ratio yaitu perumusannya antara lain:

\section{Firm Age $=$ The Number of Years Since Establishment}

Penelitian ini menggunakan aplikasi Eviews 10 dalam mengolah data dan menganalisis data yang diteliti. Terdapat beberapa pengujian yang akan

\section{PEMBAHASAN}

Hasil Uji Statistik

Uji statistik deskriptif menggambarkan tentang ringkasan data penelitian seperti dilakukan yaitu uji Chow, uji Hausman, uji regresi berganda, uji $\mathrm{R}_{2}$, uji $\mathrm{F}$, dan uji t. mean, standar deviasi, minimum, dan maksimum. Hasil uji disajakan dalam tabel berikut:

Tabel 1 Hasil Uji Deskriptif

\begin{tabular}{cccccc} 
& ROA & DER & CR & LNASSET & AGE \\
Mean & 0.058462 & 0.756967 & 2.566590 & 29.318090 & 27.485710 \\
Maximum & 0.185760 & 3.700960 & 9.392400 & 31.670070 & 45.000000 \\
Minimum & 0.000350 & 0.000940 & 0.536460 & 25.892290 & 2.000000 \\
Std. Dev. & 0.044696 & 0.560813 & 1.986130 & 1.269035 & 10.022200 \\
\hline
\end{tabular}

Kinerja Keuangan Perusahaan (ROA) memiliki nilai minimum sebesar 0.000350, nilai maksimum sebesar 0.185760, nilai rata - rata sebesar 0.058462, dan standar deviasi sebesar 0.044696. Leverage (DER) memiliki nilai minimum sebesar 0.000940 , nilai maksimum sebesar 3.700960, nilai ratarata sebesar 0.756967, dan standar deviasi sebesar 0.560813. Likuiditas
(CR) memiliki nilai minimum sebesar 0.53646, nilai maksimum sebesar 9.39240, nilai rata - rata sebesar 2.56659, dan standar deviasi sebesar 1.98613. Ukuran Perusahaan (LNASSET) memiliki nilai minimum sebesar 25.89229, nilai maksimum sebesar 31.67007, nilai rata - rata sebesar 29.31809, dan standar deviasi sebesar 1.269035. Umur Perusahaan 
(AGE) memiliki nilai minimum 2,000000, nilai maksimum sebesar 45.00000, nilai rata - rata sebesar 27.48571, dan standar deviasi sebesar 10.02220. Uji Likelihood dilakukan untuk menentukan model penelitian yang lebih baik untuk digunakan antara Common Effect Model atau Fixed Effect Model. Hasil uji disajikan dalam tabel berikut :

\section{Tabel 2 Hasil Uji Likelihood}

\begin{tabular}{lrrr}
$\begin{array}{l}\text { Ređundant Fixed Effects Tests } \\
\text { Equation: FIX }\end{array}$ & & & \\
Test cross-section fixed effects & & & \\
\hline \hline Effects Test & Statistic & d.f. & Prob. \\
\hline \hline Cross-section F & 7.869620 & $(34,66)$ & 0.0000 \\
Cross-section Chi-square & 170.119867 & 34 & 0.0000 \\
\hline \hline
\end{tabular}

Berdasarkan tabel tersebut, dapat dilihat bahwa nilai signifikansi sebesar 0.0000 yang berarti lebih kecil dari $\alpha$ sebesar 0.05 menunjukkan lebih baik menggunakan fixed effect model. Uji
Hausman dilakukan untuk menentukan model yang terbaik untuk digunakan pada penelitian antara Fixed Effect Model dan Random Effect Model. Hasil uji disajikan dalam tabel berikut :

Tabel 3 Hasil Uji Hausman

Correlated Random Effects - Hausman Test

Equation: RANDOM

Test cross-section random effects

\begin{tabular}{lrrr}
\hline \hline Test Summary & $\begin{array}{r}\text { Chi-Sq. } \\
\text { Statistic }\end{array}$ & Chi-Sq. d.f. & Prob. \\
\hline \hline Cross-section random & 38.727282 & 4 & 0.0000 \\
\hline \hline
\end{tabular}

Berdasarkan tabel 3 di atas, probabilitas yang dihasilkan pada uji hausman adalah $\alpha<0.05$. Artinya lebih baik menggunakan Fixed Effect Model 
daripada Random Effect Model. Uji

Regresi linier berganda bertujuan untuk mengetahui apakah terdapat adanya pengaruh variabel independen terhadap variabel dependen. Hasil uji disajikan dalam tabel berikut :

Tabel 4 Hasil Uji Regresi Linear Berganda

\begin{tabular}{|c|c|c|c|c|}
\hline \multicolumn{5}{|c|}{$\begin{array}{l}\text { Dependent Variable: ROA } \\
\text { Method: Panel Least Squares } \\
\text { Date: } 12 / 07 / 18 \text { Time: } 19: 45 \\
\text { Sample: } 20152017 \\
\text { Periods included: } 3 \\
\text { Cross-sections included: } 35 \\
\text { Total panel (balanced) observations: } 105\end{array}$} \\
\hline Variable & Coefficient & Std. Error & t-Statistic & Prob. \\
\hline $\mathrm{C}$ & 0.827510 & 0.670615 & 1.233957 & 0.2216 \\
\hline DER & -0.012494 & 0.008041 & -1.553858 & 0.1250 \\
\hline $\mathrm{CR}$ & -0.027201 & 0.003776 & -7.204141 & 0.0000 \\
\hline LNASSET & -0.024719 & 0.024960 & -0.990335 & 0.3256 \\
\hline AGE & 0.001271 & 0.003777 & 0.336396 & 0.7376 \\
\hline
\end{tabular}

Berdasarkan tabel 4, dapat terbentuk persamaan regresi ganda yang berfungsi untuk melihat pengaruh yang dimiliki dari setiap variabel independen terhadap variabel dependen. Berikut persamaan regresi linier berganda yang terbentuk dalam penelitian ini :

ROA $=0.827510-0.012494 \mathrm{DER}-0.027201 \mathrm{CR}-0.024719 \mathrm{LNASSET}+0.001271 \mathrm{AGE}$ $+\mathrm{e}$

Uji koefesien determinasi (Adjusted R2) memiliki tujuan untuk mengukur tingkat pengaruh variabel independen terhadap variabel dependen. Hasil pengujian disajikan dalam tabel berikut:

Tabel 5 Hasil Uji Koefesien Determinasi (Adjusted R2)

\begin{tabular}{lllr}
\hline \hline & & & \\
R-squared & 0.825707 & Mean dependent var & 0.058462 \\
Adjusted R-squared & 0.725356 & S.D. dependent var & 0.044696 \\
S.E. of regression & 0.023424 & Akaike info criterion & -4.391595 \\
Sum squared resid & 0.036212 & Schwarz criterion & -3.405838 \\
Log likelihood & 269.5587 & Hannan-Quinn criter. & -3.992147 \\
F-statistic & 8.228213 & Durbin-Watson stat & 2.458536 \\
Prob(F-statistic) & 0.000000 & & \\
\hline \hline
\end{tabular}


Berdasarkan tabel 5, dapat disimpulkan bahwa nilai Adjusted $R$-squared adalah sebesar 0.725356 atau sebesar $72.54 \%$. Nilai tersebut memiliki arti bahwa $72.54 \%$ variabel kinerja keuangan perusahaan (companies financial performance) dipengaruhi oleh variabel leverage (DER), likuiditas (CR), ukuran perusahaan (LNASSET), dan umur perusahaan (AGE) sedangkan sisanya sebesar $27.46 \%$ dipengaruhi oleh faktor - faktor lain diluar variabel independen yang digunakan dalam penelitian ini. Uji Signifikansi Simultan (Uji F) bertujuan untuk menunjukkan apakah variabel independen berpengaruh secara simultan terhadap variabel dependen. Hasil uji disajikan dalam tabel berikut :

Tabel 6 Hasil Signifikansi Simultan (Uji F)

\begin{tabular}{lllr}
\hline \hline & & & \\
R-squared & 0.825707 & Mean dependent var & 0.058462 \\
Adjusted R-squared & 0.725356 & S.D. dependent var & 0.044696 \\
S.E. of regression & 0.023424 & Akaike info criterion & -4.391595 \\
Sum squared resid & 0.036212 & Schwarz criterion & -3.405838 \\
Log likelihood & 269.5587 & Hannan-Quinn criter. & -3.992147 \\
F-statistic & 8.228213 & Durbin-Watson stat & 2.458536 \\
Prob(F-statistic) & 0.000000 & & \\
\hline \hline
\end{tabular}

Berdasarkan tabel 6, dapat diartikan bahwa nilai signifikansi yang dilihat pada bagian Prob (F-Statistic) memiliki nilai lebih kecil dari 5\% yaitu sebesar 0.000000, sehingga dapat disimpulkan bahwa seluruh variabel independen secara bersamaan (simultan) berpengaruh secara signifikan terhadap variabel dependen dalam penelitian ini. Uji $\mathrm{t}$ digunakan untuk mengetahui apakah terdapat pengaruh variabel independen terhadap variabel dependen secara individual. Hasil uji disajikan dalam tabel berikut :

Tabel 7 Hasil Uji t

\begin{tabular}{|c|c|c|c|c|}
\hline \multicolumn{5}{|c|}{$\begin{array}{l}\text { Dependent Variable: ROA } \\
\text { Method: Panel Least Squares } \\
\text { Date: } 12 / 07 / 18 \text { Time: } 19: 45 \\
\text { Sample: } 20152017 \\
\text { Periods included: } 3 \\
\text { Cross-sections included: } 35 \\
\text { Total panel (balanced) observations: } 105\end{array}$} \\
\hline Variable & Coefficient & Std. Error & $\mathrm{t}$-Statis tic & Prob. \\
\hline C & 0.827510 & 0.670615 & 1.233957 & 0.2216 \\
\hline DER & -0.012494 & 0.008041 & -1.553858 & 0.1250 \\
\hline CR & -0.027201 & 0.003776 & -7.204141 & 0.0000 \\
\hline LNASSET & -0.024719 & 0.024960 & -0.990335 & 0.3256 \\
\hline AGE & 0.001271 & 0.003777 & 0.336396 & 0.7376 \\
\hline
\end{tabular}


Nilai signifikansi untuk variabel leverage, ukuran perusahaan, dan umur perusahaan lebih besar dari 0.05 yang artinya variabel tersebut tidak memiliki pengaruh yang signifikan terhadap kinerja keuangan perusahaan. Nilai

\section{KESIMPULAN}

Berdasarkan hasil pengujian yang telah dilakukan, hipotesis pertama yang diajukan dalam penelitian ini ditolak. Hasil penelitian ini sesuai dengan penelitian yang telah dilakukan sebelumnya oleh Utami dan Pardanawati (2016) yang menyatakan leverage tidak memiliki pengaruh yang signifikan terhadap kinerja keuangan perusahaan. Tetapi tidak sejalan dengan penelitian Almajali (2012) yang menyatakan leverage memiliki pengaruh yang positif dan signifikan terhadap kinerja keuangan perusahaan. Hal ini dikarenakan karena penggunaan hutang oleh perusahaan tidak mampu meningkatkan total pendapatan maupun keuntungan perusahaan, apabila perusahaan menggunakan hutang untuk meningkatkan keuntungan maka bunga yang timbul atas hutang tersebut juga akan meningkat sehingga perusahaan harus menanggung beban bunga atas signifikansi untuk variabel likuiditas lebih kecil dari 0.05 yang artinya variabel tersebut memiliki pengaruh yang signifikan terhadap kinerja keuangan perusahaan.

hutang tersebut. Hipotesis kedua berdasarkan hasil pengujian yang telah dilakukan, hipotesis tersebut diterima. Hasil penelitian ini sesuai dengan penelitian yang dilakukan oleh Waswa, Mukras, dan Oima (2018) yang menyatakan bahwa likuiditas memiliki pengaruh yang negatif dan signifikan terhadap kinerja keuangan perusahaan. Akan tetapi hasil penelitian ini bertolakbelakang dengan hasil penelitian Deitiana dan Habibuw (2015) yang menyatakan likuiditas tidak memiliki pengaruh terhadap kinerja keuangan perusahaan. Likuiditas memiliki pengaruh yang negatif dan signifikan terhadap kinerja keuangan karena penempatan dana yang berlebihan pada sisi aktiva akan memiliki dua efek yang sangat berlainan. Pada satu sisi, tingkat likuiditas yang dimiliki oleh perusahaan akan semakin membaik. Namun di sisi lain, perusahaan akan kehilangan kesempatan untuk mendapatkan 
tambahan keuntungan yang merupakan indikator dari kinerja keuangan perusahaan karena dana yang dialokasikan untuk kegiatan investasi dan kegiatan lain yang memberikan keuntungan bagi perusahaan dicadangkan untuk memenuhi likuiditas perusahaan. Hipotesis ketiga dalam penelitian ini berdasarkan hasil pengujian yang telah dilakukan, hipotesis tersebut ditolak. Hasil penelitian ini sesuai dengan penelitian yang dilakukan oleh Deitiana dan Habibuw (2015) yang menyatakan bahwa ukuran perusahaan tidak memiliki pengaruh yang signifikan terhadap kinerja keuangan perusahaan. Hasil tersebut tidak sejalan dengan hasil penelitian Asad Abbas et.al (2013) yang menyatakan bahawa ukuran perusahaan memiliki pengaruh yang positif dan signifikan terhadap kinerja keuangan perusahaan. Hal ini dapat terjadi karena perusahaan yang memiliki ukuran yang besar belum tentu akan menjamin bahwa kinerja keuangan perusahaan tersebut baik karena perusahaan yang berukuran besar biasanya tidak selalu melakukan investasi baru yang terkait dengan ekspansi perusahaan sebelum hutang-hutang perusahaan sudah dipenuhi, dimana apabila investasi tersebut dilakukan maka hal tersebut dapat meningkatkan tingkat keuntungan yang dapat dihasilkan oleh perusahaan tersebut. Hipotesis keempat berdasarkan hasil pengujian yang telah dilakukan, hipotesis tersebut ditolak. Hasil penelitian ini sesuai dengan penelitian yang dilakukan Arisadi, Djumahir, dan Djazuli (2013) yang menyatakan bahwa umur perusahaan tidak memiliki pengaruh yang signifikan.Tetapi hasil penelitian tersebut berbeda dengan penelitian Omondi (2013) yang menyatakan bahwa umur perusahaan memiliki pengaruh yang positif dan signifikan terhadap kinerja keuangan perusahaan. Umur perusahaan tidak memiliki pengaruh terhadap kinerja keuangan perusahaan karena umur perusahaan yang lama tidak menjamin akan meningkatkan tingkat laba yang dihasilkan perusahaan tersebut. Berdasarkan penelitian yang telah dilakukan, dapat disimpulkan bahwa variabel leverage, ukuran perusahaan, dan umur perusahaan tidak memiliki pengaruh yang signifikan terhadap kinerja keuangan perusahaan. Sedangkan, variabel likuiditas memiliki pengaruh yang signifikan terhadap kinerja keuangan perusahaan. Pada penelitian ini masih terdapat beberapa 
keterbatasan yang mungkin akan berpengaruh terhadap hasil penelitian, yaitu sebagai berikut : (1) Penelitian ini hanya menggunakan perusahaan property dan real estate yang terdaftar dalam Bursa Efek Indonesia (BEI), (2) Penelitian ini hanya dilakukan pada periode yang cukup terbatas yaitu hanya selama tiga tahun yaitu pada tahun 2015 - 2017, (3) Variabel independen dalam penelitian ini hanya memiliki empat variabel yaitu leverage, likuiditas, ukuran perusahaan, dan umur

\section{DAFTAR PUSTAKA}

Jensen, M.C \& Meckling, W.H. (1976). Theory of the Firm : Managerial Behavior, Agency Costs and Ownership Structure. Journal of

Financial Economics, October, 1976, . V. 3, No. 4, pp. 305-360.

Brigham, Eugene F dan Houston (2006). Fundamental of Financial Management : Dasardasar Manajemen Keuangan Edisi 10. Jakarta : Salemba Empat.

Pantow, M.S.R., Murni, S., \& Trang, I. (2015). Analisa Pertumbuhan Penjualan, Ukuran Perusahaan, Return On Asset, dan Struktur Modal Terhadap Nilai Perusahaan yang Tercatat di Indeks LQ45. Jurnal EMBA, 3(1), 961-971.

Utami, W.B \&Pardanawati, S.L. (2016). perusahaan. Berdasarkan hasil dan keterbatasan di atas, maka saran yang dapat diberikan untuk melakukan penelitian selanjutnya yaitu menggunakan perusahaan selain perusahaan property dan real estate seperti infrastruktur, pertanian, dan pertambangan, menambah jangka waktu tahun penelitian tidak hanya tiga tahun saja, menambah variabel independen lain selain leverage, likuiditas, ukuran perusahaan, dan umur perusahaan.

Pengaruh Likuiditas, Solvabilitas, dan Manajemen Aset Terhadap Kinerja Keuangan Pada Perusahaan Go Publik Yang Terdaftar Dalam Kompas 100 di Indonesia. Jurnal Akuntansi dan Pajak, Vol.17, No.1, Juli 2016.

Aljamali, A.Y. (2012). Factors

Affecting the Financial Performance of Jordanian Insurance Companies Listed at Amman Stock Exchange. Journal of Management Research, Vol 4, No. 2.

Waswa, C.W., Mukras, M.S., \& Oima, D. (2018). Effect of Liquidity on Financial Performance of the Sugar Industry in Kenya. International Journal of Education and Research, Vol. 6, No. 6. 
Deitiana, T. \& Habibuw, L.G. (2015).

Factors Affecting the Financial Performance of Property and Real Estate Companies Listed at Indonesia Stock Exchange. Asian Business Review, Volume 5, Number 2/2015 (Issue 11)

Abbas, A., Naqvi, H.A., \& Mirza, H.H. (2013). Impact of Large Ownership on Firm Performance : A Case of non Financial Listed Companies of Pakistan. World Applied Sciences Journal 21 (8) :1141-1152

Arisadi, Y.C., Djumahir\& Djazuli, A.

(2013). Pengaruh Ukuran Perusahaan, Umur Perusahaan, Current Ratio, Debt to Equity Ratio, dan Fixed Asset to Total Asset Ratio terhadap Kinerja Keuangan pada Perusahaan Manufaktur di Bursa Efek Indonesia. Jurnal Aplikasi Manajemen, Volume 11, Nomor 4, Desember 2013.

Omondi, M.M. (2013). Factors

Affecting the Financial Performance of Listed Companies at the Nairobi Securities Exchange in Kenya. Research Journal of Finance and Accounting, Vol.4, No.15, 2013 